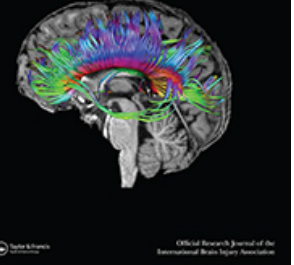

\title{
Discontinuation of artificial nutrition and hydration and covert cognition
}

\section{R. Formisano \& N. Zasler}

To cite this article: R. Formisano \& N. Zasler (2020) Discontinuation of artificial nutrition and hydration and covert cognition, Brain Injury, 34:8, 1135-1135, DOI: 10.1080/02699052.2020.1786602

To link to this article: https://doi.org/10.1080/02699052.2020.1786602

曲 Published online: 28 Jun 2020.

Submit your article to this journal $₫$

Џ Article views: 64

Q View related articles $₫$

View Crossmark data 


\title{
Discontinuation of artificial nutrition and hydration and covert cognition
}

\author{
R. Formisano $\mathbb{D}^{\mathrm{a}}$ and N. Zasler ${ }^{\mathrm{b}, \mathrm{c}, \mathrm{d}}$
}

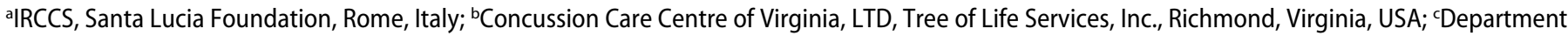
of Physical Medicine and Rehabilitation, Virginia Commonwealth University, Richmond, Virginia, USA; ${ }^{\mathrm{d}}$ Department of Physical Medicine and Rehabilitation, University of Virginia, Charlottesville, Virginia, USA

ARTICLE HISTORY Received 30 April 2020; Accepted 19 June 2020

\section{Letter}

Van Erp and coauthors (1) reported a comprehensive care trajectory of persons with prolonged disorders of consciousness (DoC) and the possible vicious circle of their outcomes. The topic of clinical misdiagnosis and the utility of specific assessment by means of CRS-R and advanced diagnostic techniques were only briefly treated by the same authors, whereas it should be of paramount importance, especially in end of life decision-making and discontinuation of artificial nutrition and hydration (ANH) (2).

Also, the role of caregivers in the behavioral assessment of persons with DoC was just mentioned, whereas its importance has been previously emphasized by several authors $(3,4)$, as being a critical component of the bedside assessment of patients with disorders of consciousness.

The authors appropriately reported the use of midazolam and morphine during ANH withdrawal. It should be noted however that there are scarce data available on pain perception during $\mathrm{ANH}$ withdrawal. Interesting findings have been previously noted in persons with DoC by means of advanced diagnostic techniques (5) and specific clinical tools such as Nociception Coma Scale $(6,8)$, also with personalized painful stimulation (9).

The aim of this letter is twofold:

(1) To espouse for inclusion of caregivers in the bedside behavioral assessment of persons with DoC and to use diagnostic advanced techniques to ascertain or exclude the presence of covert cognition. From an ethical, legal, moral, and medical perspective, these issues are quite relevant to cases of $\mathrm{ANH}$ decision-making (10).

(2) To advocate for controlled studies on pain perception, possibly by means of advanced diagnostic techiques, in persons with DoC including during $\mathrm{ANH}$ withdrawal, to assess issues of pain and suffering.

\section{Funding}

This work has received funding from the European Union's Horizon 2020 research and innovation programme under the Marie Skłodowska-Curie [grant agreement No 778234.].

\section{ORCID}

R. Formisano (D) http://orcid.org/0000-0002-2516-0540

\section{References}

1. van Erp WS, Lavrijsen JCM, Vos PE, Laureys S, Koopmans RT. Unresponsive wakefulness syndrome: outcomes from a vicious circle. Ann Neurol. 2019 Jan;1-7. doi:10.1002/ana.25624.

2. Fins JJ, Bernat JL. Ethical, palliative, and policy considerations in disorders of consciousness. Neurol. 2018 May;91:471-75. doi:10.1212/WNL.0000000000007519.

3. Sattin D, Giovannetti AM, Ciaraffa F, Covelli V, Bersano A, Nigri A, Ferraro S, Minati L, Rossi D, Duran D, et al. Assessment of patients with disorder of consciousness: do different Coma Recovery Scale scoring correlate with different settings? J Neurol. 2014 Dec;261(12):2378-86. doi:10.1007/s00415-014-7478-5.

4. Formisano R, Contrada M, Iosa M, Ferri G, Schiattone S, Aloisi M. Coma Recovery Scale - revised with and without the emotional stimulation of caregivers. Can J Neurol Sci/J Can des Sci Neurol. 2019 Sept;46(5):607-09. doi:10.1017/cjn.2019.227.

5. Boly M, Faymonville ME, Schnakers C, Peigneux P, Lambermont B, Phillips C, Lancellotti P, Luxen A, Lamy M, Moonen G, et al. Perception of pain in the minimally conscious state with PET activation: an observational study. Lancet Neurol. 2008 Nov 1;7(11):1013-20. doi:10.1016/S14744422(08)70219-9.

6. Schnakers C, Chatelle C, Vanhaudenhuyse A, Majerus S, Ledoux D, Boly M, Bruno MA, Boveroux P, Demertzi A, Moonen G, et al. The Nociception Coma scale: a new tool to assess nociception in disorders of consciousness. Pain. 2010 Feb;148 (2):215-19. doi:10.1016/j.pain.2009.09.028.

7. Chatelle C, Majerus S, Whyte J, Laureys S, Schnakers C. A sensitive scale to assess nociceptive pain in patients with disorders of consciousness. J Neurol Neurosurg Psychiatry. 2012 Dec;83 (12):1233-37. doi:10.1136/jnnp-2012-302987.

8. Chatelle C, Thibaut A, Whyte J, De Val MD, Laureys S, Schnakers C. Pain issues in disorders of consciousness. Brain Inj. 2014 Aug;28(9):1202-08. doi:10.3109/02699052.2014.920518.

9. Formisano R, Contrada M, Aloisi M, Ferri G, Schiattone S, Iosa M, Buzzi MG. Nociception Coma Scale with personalized painful stimulation versus standard stimulus in non-communicative patients with disorders of consciousness. Neuropsychological Rehabil. 2019 May;10:1-2. doi:10.1080/09602011.2019.1614464.

10. Zasler ND, Aloisi M, Contrada M, Formisano R. Disorders of consciousness terminology: history, evolution and future directions. Brain Inj. 2019 Sep;9:1-6. doi:10.1080/02699052.2019.1656821. 